University of Nebraska - Lincoln

DigitalCommons@University of Nebraska - Lincoln

May 2008

\title{
The National Assessment of Educational Progress in Economics: Findings for General Economics
}

\author{
WILLIAM WALSTAD \\ University of Nebraska-Lincoln, wwalstad1@unl.edu \\ Stephen Buckles \\ Vanderbilt University, Nashville, TN
}

Follow this and additional works at: https://digitalcommons.unl.edu/cbafacpub

Part of the Business Commons

WALSTAD, WILLIAM and Buckles, Stephen, "The National Assessment of Educational Progress in Economics: Findings for General Economics" (2008). College of Business Faculty Publications. 42. https://digitalcommons.unl.edu/cbafacpub/42

This Article is brought to you for free and open access by the Business, College of at DigitalCommons@University of Nebraska - Lincoln. It has been accepted for inclusion in College of Business Faculty Publications by an authorized administrator of DigitalCommons@University of Nebraska - Lincoln. 


\title{
ASSESSMENT OF ECONOMICS IN US HIGH SCHOOLS AND UNDERGRADUATE PROGRAMS'
}

\section{The National Assessment of Educational Progress in Economics: Findings for General Economics}

\author{
By William B. Walstad and Stephen Buckles*
}

Since 1969, achievement studies have been conducted in various subjects in elementary and secondary school curricula as part of the National Assessment of Educational Progress (NAEP). Economics has now been added to the list. This study offers a brief description of the NAEP test in economics and presents some findings from the 2006 assessment given to twelfth-grade students who were taking a general economics course.

NAEP is mandated by Congress and administered by the National Center for Education Statistics (NCES) at the US Department of Education. Policy direction and review are under the control of the National Assessment Governing Board (NAGB). For the economics assessment, the National Council on Economic Education, the American Institutes for Research, and the Council of Chief State School Officers developed a content framework for economics in 2001. These organizations established several committees composed of economists, educators, business and government leaders, and testing experts to prepare the assessment framework, subject to final approval by the NAGB.'

The major decision for the test developers was what economics content should be included in the test. Most economics courses in high schools last for a semester and cover basic

† Discussants: Alan Krueger, Princeton University; Wendy A. Stock, Montana State University; Tisha L. N. Emerson, Baylor University.

* Walstad: Department of Economics, 339 College of Business Administration, University of Nebraska-Lincoln, Lincoln, NE 68588-0402 (e-mail: wwalstad1@unl.edu); Buckles: Department of Economics, Vanderbilt University, 417 Calhoun, Box 1819B, Nashville, TN 37235 (e-mail: Stephen.Buckles@Vanderbilt.edu).

I For a copy and details see www.nagb.org/frameworks/ economics_06.pdf. microeconomic and/or macroeconomic concepts and applications. Some economics courses are Advanced Placement or honors courses that focus on college-level principles of economics. There are also combined courses in economics with government. A limited amount of economics content also may be taught in such subjects as consumer economics or personal finance, business education or entrepreneurship, history, and government (Walstad 2001). Given these conditions, the framework had to cover the broad range of what high school students might be taught about economics. A decision was made to target the assessment at what would likely be taught in a general economics course for highschool students and the document used for content specification was the Voluntary National Content Standards in Economics.

\section{Data and Sample}

The testing for the NAEP in economics was conducted in March 2006. The data were collected from a nationally representative sample of 11,490 twelfth-grade students in 590 public and nonpublic schools to represent a target population of 3,059,000 students. Following typical NAEP procedures, the sample was selected using a stratified, three-stage design that involved sampling students from selected public and private schools across the nation. NAEP data were then weighted by various factors so that the sample results can be used to draw valid

\footnotetext{
${ }^{2}$ See www.nceenet. The standards were used for NAEP economics as originally written. but the underlying benchmarks were revised, and a benchmark on the time value of money was added. The content of the NAEP test is similar to another high school test (Walstad and Ken Reheck 2001).
} 
inferences about the population (Eugene G. Johnson 1989).

The school participation rate for the economics assessment was 79 percent and the student participation rate was 72 percent. NCES standards require that the data be studied for nonreponse bias if the participation rate for schools or students falls below 85 percent. Further NCES analysis found that nonresponse adjustments and school substitution reduced the observable nonresponse for schools and students. The NAGB also requires that the results not be reported for any major subgroup for which the participation rate falls below 70 , which in the case of the economics assessment applied to the results for the western region and for private schools.

After a year of preparation, the NCES presented general findings at a press conference in August 2007, and released a published report (Nancy Mead and Brent Sandene 2007). ${ }^{3}$ This report presents the overall results for all students and offered some breakdowns of the findings by demographics. Results on NAEP assessments are reported as scale scores and by achievement levels. The scale scores for economics are set from 0 to 300 , with a mean of 150 . The three achievement levels are basic, proficient, and advanced. Students at or above the basic level demonstrate partial mastery of the prerequisite knowledge and skills that are fundamental for proficient work. Students at the proficient level demonstrate solid academic performance by showing competency, including subject-matter knowledge, application of such knowledge to real-world situations, and analytical skills appropriate to the subject matter. Students at the advanced level demonstrate superior performance on each of the testing tasks. Seventynine percent of the students scored at or above the basic level (a scale score of 123 and above); 42 percent performed at or above the proficient level (160 and above); and 3 percent were in the advanced level (at and above 208). The report also contained some of the 53 released questions from the assessment, and it provided item maps that described the content of economics items and their relative difficulty for students. ${ }^{4}$

\footnotetext{
${ }^{3}$ Available at: http://nces.ed.gov/nationsreportcard/ economics.

${ }^{4}$ All released items are available at: http://nces.ed.gov/ nationsreportcard/itmrls/.
}

To permit the subgroup and background analyses, the NAEP collects data through background questionnaires administered to students, their teachers, and the school principal or a designee. ${ }^{5}$ Some of these questions are standard for every NAEP assessment and cover student demographics. Other background information is collected on factors such as coursework, instructional practices, and other influences that might affect academic performance. When data on the scale scores are combined with the survey data, a sizable dataset for further analysis is created. NCES placed the dataset online with access through its NAEP Data Explorer (NDE). ${ }^{6}$

\section{Results for General Economics}

One variable created for the NDE dataset classified all high school students into five types based on whether students responded yes to having taken such courses in grades 9 through 12: (a) general economics (49 percent); (b) advanced economics (Advanced Placement, International Baccalaureate, or honors that are typically college oriented; 16 percent); (c) combined (courses or units in government and economics; 12 percent); (d) consumer/business (consumer economics or personal finance or business principles; 11 percent); and (e) no economics (none of all the types of courses above were taken; 13 percent). ${ }^{7}$ The current study focuses on the general economics students because this group is the largest segment of the high-school sample, the NAEP content framework was targeted at general economics, and there may be more similarity among the general economics courses than with other course types.

The survey results can be used to identify student, teacher, or school factors that appear to be associated with sizable differences in test scores. The responses to the student survey will be given the most attention because many of the school and teacher items are only indirectly connected with students. The results are largely exploratory and descriptive, but they are

\footnotetext{
${ }^{5}$ For the economics surveys, go to: http://nces.ed.gov/ nationsreportcard/bgquest.asp.

${ }^{6} \mathrm{http}: / / \mathrm{nces} . e d . g o v /$ nationsreportcard/nde.

${ }^{7}$ The NDE coursework variable may overstate coursework when compared with another coursework variable, but the alternative also has its limitations.
} 
Table 1-General ECONOMics SCORES by Demographics

\begin{tabular}{lrrr}
\hline \hline & Score & s.e. & $\%$ \\
\hline Total scale score (0-300) & 151 & 1.0 & 100 \\
HS program: academic & 159 & 1.2 & 51 \\
HS program: general or vo-tech & 143 & 1.1 & 49 \\
Male & 154 & 1.0 & 51 \\
Female & 148 & 1.2 & 49 \\
White & 159 & 0.9 & 64 \\
Black or African American & 131 & 1.4 & 13 \\
Hispanic & 136 & 1.1 & 15 \\
Asian American/Pacific Islander & 151 & 4.4 & 5 \\
Parents' education: & & & \\
$\quad$ High school or less & 138 & 1.3 & 30 \\
$\quad$ Some college & 150 & 1.0 & 24 \\
College graduate & 159 & 1.1 & 47 \\
Books in the home: & & & \\
$\quad$ 0 to 25 & 136 & 1.2 & 28 \\
26 to 100 & 151 & 1.1 & 38 \\
$\quad$ More than 100 & 163 & 0.9 & 34 \\
School lunch program: & & & \\
$\quad$ Eligible & 136 & 1.0 & 24 \\
$\quad$ Ineligible or unknown & 156 & 1.0 & 76 \\
\hline
\end{tabular}

suggestive of what might be found when causal modeling is conducted with the released data.

As shown in Table 1, the mean scale score for students in general economics is $151 .^{8}$ This average score masks differences by the type of high school program. For example, about half of the students are enrolled in an academic or college preparatory program. The other half are enrolled in either a general program (43 percent) or vocational and technical programs (5 percent). Students in academic programs have a significantly higher score than other students.

Demographic factors showed significant differences among students taking general economics, as has been the case with results from NAEP achievement tests at the twelfth grade in many other subjects. Males significantly outscored females. Whites and Asian Americans and Pacific Islanders scored significantly higher than did African Americans and Hispanics.

In addition, several socioeconomic indicators show substantial differences. Those students whose parents had only a high-school education or did not graduate from high school had significantly lower average scores, compared with the scores for students whose parents had some

\footnotetext{
${ }^{8}$ Although average scores vary by course type (e.g., advanced) in expected ways, useful comparisons need more precision for some types and more analysis than is possible with NDE.
}

college, which in turn was significantly lower than the scores for students whose parents were college graduates. The number of books a student reported having in a home is another socioeconomic indicator. As the number increases from $0-25$ to $26-100$ to 100 or more, there is a significant increase in test scores. A third socioeconomic indicator is taken from the school survey and reports on whether a student tested was eligible for a free school lunch. Those students who are eligible have significantly lower scores than those who are ineligible or for whom there is no information.

As shown in Table 2, student perceptions often reflect the level of understanding students demonstrate in a general economics course. In fact, the responses to several questions provide evidence on the validity of the test. An expected inverse relationship was found between the perceived difficulty of the test and achievement. When asked how hard this test was compared with other tests taken this school year, those students who said the test was harder than others had significantly lower test scores than those students who said the test was easier than other ones they had taken. Another expected inverse relationship was found with student effort. The students who said they tried harder or much harder on this test as on other tests had significantly lower achievement scores than other students, presumably because they had less ability or were less prepared. Students who said they did not try as hard on this test as on other tests did significantly better than the first group, most likely because this was a higher ability group or a more prepared group who could afford to relax somewhat on this test and still do well. The students with the highest scores, however, were those who said they tried as hard on this test as on other tests, indicating that putting forth their typical effort on this test produced results.

An economics course likely influences students' perceptions of what they gain from a course in predictable ways. Eighty-seven percent of general economics students agreed that the course had helped them understand the US economy. Most students (over eight in ten) agreed that taking the general economics course helped them understand more about current events and public policy. Students who expressed agreement on these two course outcomes had significantly higher scores compared with those students who disagreed. 
Table 2-General Economics by Opinions and Perceptions

\begin{tabular}{llll}
\hline \hline Survey items & Score & s.e. & Percent \\
\hline Test difficulty: & 155 & 1.2 & 48 \\
$\quad$ Easier than others & 151 & 1.2 & 37 \\
As hard as others & 145 & 1.3 & 15 \\
Harder than others & 149 & 1.4 & 40 \\
Test effort: & 156 & 1.1 & 51 \\
Tried not as hard as on other tests & 139 & 2.0 & 9 \\
Tried as hard as on other tests & & & \\
Tried harder than on other tests & 152 & 1.0 & 81 \\
Course helped me understand: & 148 & 1.5 & 19 \\
Current events \& public policy: agree & 153 & 1.0 & 87 \\
Current events \& public policy: disagree & 141 & 1.6 & 13 \\
US economy: agree & 152 & 1.0 & 72 \\
US economy: disagree & 150 & 1.3 & 28 \\
International economy: agree & 151 & 1.1 & 71 \\
International economy: disagree & 152 & 1.1 & 29 \\
Personal finances: agree & 149 & 1.1 & 64 \\
Personal finances: disagree & 156 & 1.1 & 36 \\
Choices about future education: agree & & & \\
Choices about future education: disagree & 160 & 1.0 & 58 \\
Plans after high school: & 143 & 1.2 & 20 \\
Four-year college & 138 & 1.4 & 22 \\
Two-year college & & & \\
Work/business education/military/other & & & \\
\hline
\end{tabular}

There was slightly less agreement (about seven in ten) among students with the notion that the course helped improve understanding of personal finance and understanding of the international economy. For these two outcomes, there was no validating information in the form of a significant difference in test scores for those students who agreed or disagreed. These results were expected. Personal finance is taught only tangentially in most general economics courses. International economics is sometimes taught, but typically at the end of a course when there are time constraints, and teachers are less prepared to handle this more complex content. A smaller percentage of students (six in ten) thought a general economics course helped them make choices about their future education and career. The scores for those students who agreed were significantly lower than the scores for those students who disagreed with the proposition.

By the time the test was conducted, most students probably had a good idea of what they planned to do after high school. The students who plan to attend four-year colleges were most likely academically inclined and so it was expected that they would score higher than students who planned to attend two-year colleges. Students who planned to work, get business training, go into the military, or do something else had significantly lower scores, as one might expect.

In Table 3, the focus turns to instructional practices and outside activities that appear to be associated with differences in test scores. In the survey, students were given a list of economics-related activities and asked to indicate which ones they participated in either for a class or as an extracurricular activity. The activity list included participating in Future Business Leaders of America, DECA (a marketing group), Junior Achievement, economics-related clubs, academic competitions, a stock market game or simulation, a student-managed school store, and a student-managed credit union or bank. Of the list, the only activity that shows a positive and significant relationship with test scores was participation in a stock market game or simulation, either as part of a class or as an extracurricular activity. Presumably this activity reinforced economic ideas that they learn in a general economics course. By contrast, there was a negative and significant association between participating in Junior Achievement and test scores, even though this activity has long been marketed as an economic education program.

Some instructional practices are associated with higher test scores. Students who are asked 
TABLE 3-General ECONOMICS By InSTRUCTION AND ACTIVITY

\begin{tabular}{|c|c|c|c|}
\hline Survey items & Score & s.e. & Percent \\
\hline Did stock market game in class & 160 & 1.2 & 34 \\
\hline No stock market game in class & 146 & 1.0 & 66 \\
\hline Did Junior Achievement in class & 142 & 3.4 & 4 \\
\hline No Junior Achievement in class & 151 & 1.0 & 96 \\
\hline In economics, write long answers & 153 & 1.1 & 66 \\
\hline Not asked to write long answers & 148 & 1.3 & 34 \\
\hline \multicolumn{4}{|l|}{ In economics use Internet: } \\
\hline Yes (once month to daily) & 153 & 1.2 & 63 \\
\hline No/rarely & 148 & 1.2 & 37 \\
\hline \multicolumn{4}{|l|}{ Pages read a day: } \\
\hline 10 or fewer & 146 & 1.0 & 59 \\
\hline 11 or more pages & 157 & 1.1 & 41 \\
\hline Students take required economics test & 159 & 2.7 & 11 \\
\hline No required district economics test & 150 & 1.1 & 89 \\
\hline \multicolumn{4}{|l|}{ Watch/read/listen to information on: } \\
\hline Personal finance: yes & 154 & 1.0 & 61 \\
\hline Personal finance: no & 147 & 1.2 & 39 \\
\hline Local economy: yes & 154 & 1.0 & 52 \\
\hline Local economy: no & 148 & 1.1 & 48 \\
\hline US economy: yes & 156 & 1.0 & 50 \\
\hline US economy: no & 146 & 1.1 & 50 \\
\hline International economy: yes & 156 & 1.1 & 41 \\
\hline International economy: no & 148 & 1.0 & 59 \\
\hline \multicolumn{4}{|l|}{ Work: } \\
\hline None to once in while & 152 & 1.2 & 46 \\
\hline 5 to 20 hours a week & 153 & 1.3 & 34 \\
\hline More than 20 hours a week & 149 & 1.3 & 19 \\
\hline
\end{tabular}

in their general economics course to write long answers to questions or assignments scored significantly higher than students who said that was never or rarely the case. Also, students who reported using the Internet fairly often (from once a week to daily) to get economic data or information for class work or homework had significantly higher scores than those students who never or rarely used the Internet for such data or information. The number of pages read a day for school or homework in all subjects distinguishes high achievers from low achievers. A related item from the school survey is also suggestive of an instructional practice that may improve test scores. Students in school districts that required students to take a standardized economics test scored significantly higher in general economics than students in districts without such tests, most likely because the testing held students and teachers accountable for learning economics. Although not reported in Table 3, the same result was found for districts that just include economics questions on a broader test covering several subjects.
Whether students watch, read, or listen to information on various topics such as personal finance, the local economy, the US economy, and the international economy are all associated with significantly higher test scores. Twelfthgrade students with general economics coursework who reported never gathering information on such topics or doing so only one or two times a year (the "no" group) had significantly lower levels of achievement compared with students who reported gathering information once or twice a month or at least once a week (the "yes" group). The results also indicate there is a lack of interest in economics because half or more of the students who took general economics reported gathering no information on the local, US, or the international economy. There is, however, more widespread interest in personal finance, with over six in ten reporting that they gather information on this topic.

The results show that, working for pay or for a family business up to about 20 hours a week is unrelated to student achievement in a general economics course. Students who work more 
than 20 hours a week, however, have significantly lower test scores.

Finally, the analysis found few teacher factors to be associated with significantly higher test scores in general economics courses. Most of the teacher data at the NDE site came from a survey of department chairs. Among the items considered were hiring requirements for teachers such as certification, college coursework, or degrees in economics. In addition, students in departments that had more teachers who took college courses in economics, had a major or minor in economics, participated in economics workshops, or had more years of experience teaching economics showed no significant differences in their scores compared to students in departments without these teacher attributes. A likely explanation of these findings is that most of the teacher data are only indirectly connected to students through estimates from department chairs. The complete analysis of teacher factors will require access to the actual teacher data and also substantial adjustment for data loss because of incomplete teacher data for many students.

The conclusion to draw from this study of the NAEP in economics is that the dataset can be a rich resource for investigating factors that affect student achievement in economics, not only in the general economics course, but also in the other types of courses and within the specific content areas of market, national, and international economics. Further study will require the use of the released dataset and analysis to control for the effects of multiple variables.

\section{REFERENCES}

Johnson, Eugene G. 1989. "Considerations and Techniques for the Analysis of NAEP Data." Journal of Educational Statistics, 14(4): 303-34.

Mead, Nancy, and Brent Sandene. 2007. The Nation's Report Card: Economics 2006. (NCES 2007-475). Washington, DC: US Department of Education.

Walstad, William B. 2001. "Economic Education in U.S. High Schools." Journal of Economic Perspectives, 15(3): 195-210.

Walstad, William B., and Ken Rebeck. 2001. "Assessing the Economic Understanding of U.S. High School Students." American Economic Review, 91(2): 452-57. 